\title{
Effect Analysis on Laboratory Work Skill Training Provided by Madda Walabu University for Secondary Schools (2013-2017G.C) in Bale Zone, South East Ethiopia
}

\author{
Abebe Adugna Chala ${ }^{1 *} \quad$ Ibrahim Kedir ${ }^{1} \quad$ Shiferaw Wami ${ }^{1}$ \\ Esayes Aklilu²(Assistant Prof.) Tekalign Kassa ${ }^{3}$ (Assistant Prof. \\ 1.College Of Natural And Computational Science Department of Physics at Madda Walabu University, P. O \\ Box 247, Bale Robe Ethiopia \\ 2.College of natural and computational Science Department of Biology at Madda Walabu University, P. O box \\ 247, Bale Robe Ethiopia \\ 3.College of natural and computational science Department of Chemistry at Madda Walabu University, P. O box \\ 247, Bale Robe Ethiopia
}

The research is financed by Madda Walabu University, Bale Robe, Ethiopia

\section{Abstract}

Incorporating Laboratory work and implementing in real context are different things. As one of community service Madda Walabu University gave training on practical skills for teachers by identifying the problems related to implication of laboratory work. The project title was "Awareness and Skill Training for natural science teachers in Secondary and preparatory School from 2013-2015G.C". Hence, the objective of this research was to analyze effect of training on the implementation laboratory work. Among 57 secondary schools in Bale zone 15 schools received the training and 42 did not. For comparison purposes 6 trained and 6 not trained schools were selected which comprise $20 \%$ form the total schools. Primary data were gathered from 72 teachers and 12 principals using in depth interview and the questionnaires for 404 Grade 10 students. Secondary data were collected from documents such as annual plans and laboratory reports, annual reports. A descriptive survey has been conducted to analyze the effect of the training on schools laboratory works. The result of the study has showed that there are no significant changes were found in implementation of laboratory works in schools as a result of the trainings. The major hindering factors for laboratory works to be functional are shortage lab technician and resources (lab materials, chemicals, well organized and separated Laboratory room) and large class size. Unless these barriers are tackled prior to the training, it is impossible to expect achievement in objectives wanted by providing only the training. Prior to the training the school environment should be facilitated to handle the implementation of the Laboratory works. The skill training is not required in the schools with poor facilities. The educational offices should seriously plan and enforce the provision of the required facilities for the schools and professional support for the teachers.

Keywords: Laboratory work Training provided, Secondary Schools, result of the training

DOI: $10.7176 / \mathrm{JEP} / 10-13-08$

Publication date:May $31^{\text {st }} 2019$

\section{Introduction}

Secondary school is the base in preparing students for science education. It is at this level they were exposed to laboratory equipment, activities and precaution or safety rules. A high school laboratory should have the equipment necessary to conduct meaningful demonstrations and experiments. However, Practical work is not done in many countries do not implement due to inadequate resources, lack of practical science skills and large classes in science Onwu \& Stoffel, 2005; Ramnarain, (2014). In South African schools teachers do not use practical work to teach physical sciences Hatting \& Rogan, 2007).

The purpose of laboratory work in science education are motivation for students, the excitement of discovery, consolidation of theory, development of manipulative skills, knowledge of standard techniques, general understanding of data handling, development of other skills (e.g. analytic, evaluative, planning, applied, mathematical) and understanding of how science works: concepts of scientific process, collaborative working, reproducible results, fair testing (Watts 2013, p.4). Learners do laboratory work to expand their knowledge in an attempt to understand the world around them (Kolucki\&Lemish, 2011). For these purposes laboratory work specified in the secondary school science curriculum should be given due attention. Otherwise teaching the students to memorize facts and formulas only encourage memorization which is contrary to the goals of science education in general and science education in particular.

Research conducted in Ethiopia indicated that secondary students do not receive the practical experiences specified in the official science curriculum Samuel Bekalo \&Geoff Welford, 2010. About 85.97\% of laboratory activities were not done in science education at secondary schools of Ilu Aba Bora zone (Feyera 2014). In the same way, about $75 \%$ students had not been engage with practical activities while learning Physics (Endalamaw and et 
al., 2017). In well organized way practical works may not be implemented in real context because of the sophisticated factors identified by different researchers which are related to school facilities, teachers' competency and motivations, teachers' work load and large class size. These barriers of the context of implementation should be properly identified and tackled. As one effort of tackling the barriers of implementation related to practical skills of the teachers, Madda Walabu university had also provided the training on "awareness and skill training for secondary school teachers on laboratory work" for three consecutive years from 2005E.C-2007E.C. Therefore, it is mandatory to investigate effect analysis on training provided by Madda Walabu University for teachers' skills capacity to the schools.

Generally, incorporating Laboratory work the curriculum and implementing in real context are different things. Smartly intended laboratory work may not be implemented in real context because of the different sophisticated factors identified by different researchers which are related to school facilities, teachers' competency and motivations, teachers' work load and large class size. As one effort of tackling the barriers of implementation related to practical skills of the teachers Madda Walabu University had also provided the training on "awareness and skill training for secondary school teachers" for three consecutive years from 2005E.C-2007E.C". Within these three years Madda Walabu University research and Community service directorate invested a total of 241000 ETB on the training as shown in the table 1.1. In many cases universities in Ethiopia provide capacity building training for school around it. But, giving the training should not be the end, and the effect analysis of the training on the improvement of the implementation of laboratory work should be conducted. Hence, there is no any research and other reports done to observe the training output yet.

Table 1.1 data of the training provided for different schools of Bale zone from the year 2005-2009 E.C (Source Madda Walabu University community service directorate and Bale Zone Educational Office)

\begin{tabular}{|c|c|c|c|c|c|}
\hline $\begin{array}{l}\text { Sr. } \\
\text { No }\end{array}$ & Year & Training Center of school & $\begin{array}{l}\text { experts } \\
\text { participated }\end{array}$ & $\begin{array}{l}\text { Trainee } \\
\text { teachers }\end{array}$ & $\begin{array}{l}\text { Budget allotted by Madda } \\
\text { Walabu University }\end{array}$ \\
\hline 1 & 2005E.C & $\begin{array}{l}\text { Ginir, Gasera, Agarfa, Goro, } \\
\text { Menna, Batu, and Dinsho, }\end{array}$ & 3 & 40 & 58,000 \\
\hline 2 & 2006E.C & $\begin{array}{l}\text { Agarfa, Gasera, Ginir, Manna } \\
\text { and Goro }\end{array}$ & 3 & 44 & 54,000 \\
\hline 3 & 2007E.C & $\begin{array}{l}\text { Welabu, HaroDumel, chelchel, } \\
\text { Angetu and Manna }\end{array}$ & 3 & 42 & 56,000 \\
\hline 4 & 2008E.C & $\begin{array}{l}\text { This time training were not } \\
\text { provided }\end{array}$ & -- & --- & --- \\
\hline 5 & 2009E.C & $\begin{array}{l}\text { Jara, Dinsho, Hobora and } \\
\text { Dodola }\end{array}$ & 4 & 38 & 73,000 \\
\hline
\end{tabular}

\section{Objectives}

The general objective of this research is to conduct effect analysis of the training provided by Madda Walabu University on awareness and skills of laboratory work and Identify factors affecting its Implementation. More specifically this research was intended to find effect analysis of training provided by Madda Walabu University on Laboratory work (2013-2015) in science for the selected Secondary Schools in Bale Zone. Additional it was to compare the extent of implementation of science laboratory work between the schools which received the training and those which were not included in the training.

The research will be carried out in 12 secondary schools of Bale zone. In these schools only grade 10 students, Science teachers, principals will be considered as the subjects of the study. The reason to exclude other grade levels is that grade 10 is an intermediate level, and valuable information is acquired from the subjects of the study for the purpose of designing appropriate intervention for the improvement of laboratory work in science.

\section{Methodology}

\subsection{Description of the Study area}

The study has been conducted in Bale zone which is located in south east Ethiopia in Oromia region. It shares common boundary with Somali National Regional State of Ethiopia in the East, East Hararge zone in Northeast, West Hararge Zone and Arsi zone in North, West Arsi Zone in the West and Guji Zone in the Southwest (Atlas of Bale zone, 2004). It is characterized by highlands, lowlands and rugged areas, incised river valleys, deep gorges and flat topped plateaus. The surfaces rises from about less than $300 \mathrm{~m}$ above sea level (Southeast Rayitu,GurraDamole and Madda Walabu) to a high ranges culminating into mountain Tulu Dimtu (4377m ), the highest peak in the zone. According to the Bale Zone Education office there are 57 secondary schools found in the zone.

\subsection{Research Design}

To extensively investigate the level of implementation of laboratory work and effectively analyze the effect of the 
training of Madda Walabu University on the implementation of laboratory work, a descriptive research design (Survey) was used.

\subsubsection{Sampling frame, Sample size and sampling techniques}

The target population was grade 10 students, science teachers, school principals of the sample schools. Among 57 secondary schools in bale zone 15 schools received the training and 42 did not. For comparison purposes 6 trained and 6 not trained schools were selected which comprise $20 \%$ of the total secondary schools in Bale zone which has been recommended by (Geneserth et al,1987) in a descriptive survey study the sample size is acceptable when $10 \%$ to $20 \%$. All the science teachers and principals in the selected schools were taken purposively since their numbers are manageable in each school.

To select sample size of grade 10 students from these schools Yamane (1967) provides a simplified formula with a 95\% confidence level and 5\% precision level (e). $n=\frac{N}{1+N\left(e^{2}\right)} \quad$ Where $\mathrm{n}=$ Sample size, $\mathrm{N}=$ Total population, $\mathrm{e}=$ precision level $=0.05$. There were about 9,425 students in total secondary schools of Bale zone currently enrolled to learn in 2010E.C. Hence based on the formula stated 384 students and 5\% that is 20 and a total of 404 students were used in this study.

2.2.2. Sources of data and data collection instruments are summarized in the following table

\begin{tabular}{|c|c|c|c|c|c|c|}
\hline $\begin{array}{l}\text { Sr. } \\
\text { No }\end{array}$ & Data source subject & Total & Sample size & $\begin{array}{l}\text { Sampling } \\
\text { method }\end{array}$ & Tools used & Remark \\
\hline 1 & Total schools & 57 & 12 & stratified & various & \\
\hline 2 & $\begin{array}{lll}\text { Schools } & \text { those } & \text { got } \\
\text { training } & & \end{array}$ & 15 & 6 & stratified & various & \\
\hline 3 & $\begin{array}{l}\text { Schools did not get } \\
\text { training }\end{array}$ & 42 & 6 & stratified & various & \\
\hline 4 & students & 9425 & 404 & Stratified & questioners & \\
\hline 5 & Science teachers & 95 & all Available & purposive & Questionnaire & \\
\hline 6 & School principal & 57 & 12 & purposive & interview & $\begin{array}{l}\text { all } \\
\text { Available }\end{array}$ \\
\hline 8 & Student science text & 1 & 1 & & document analysis & \\
\hline 11 & Class rooms & 12 & $\begin{array}{l}2 \text { times } \\
\text { periods }\end{array}$ & purposive & $\begin{array}{l}\text { observation check } \\
\text { list }\end{array}$ & \\
\hline 12 & laboratory rooms & 12 & $\begin{array}{l}2 \text { times } \\
\text { periods }\end{array}$ & purposive & $\begin{array}{l}\text { observation check } \\
\text { list }\end{array}$ & \\
\hline
\end{tabular}

Table 3.1, Sample data and sampling method (Source of the population is Zone Educational Office report of 2018)

\subsubsection{Procedure of Data Collection}

The sample size for each school was set using the target student population of each school. Subsequently, discussions were conducted with principals of each school as to how to distribute the questionnaires for students. Before the students started to fill in the questionnaire, the purpose of the study was explained by the researchers and oral instructions were also given. Observation checklists were prepared and filled for each school and in depth interview for principals was conducted as per the schedule for each school. Secondary data were collected from documents such as annual plans and laboratory reports, annual reports.

\subsubsection{Pilot Testing}

For close-ended questionnaire prepared for students, Pilot testing was conducted on a total of 50 students at Robe secondary school of grade 10 . Adjustments were made on vague questions which were raised by the students. The numbers of male and female participants were taken proportional. Finally, the responses of the participants were used and entered to SPSS version 20 to compute item inter correlation and Cronbach-Alpha in order to evaluate the scales and their reliability.

\section{Data Analysis and Interpretation}

This part of the study deals with presentation, analysis and interpretation of data gathered from students, Natural science teachers, school principals and observation checklists using instruments mentioned in the preceding chapter.

A total of 404 questionnaires were distributed for students, and 380 were returned. Among these 345 questionnaires were properly filled. From the proposed of 92 Natural science teachers 72 were available the schools and questionnaires were distributed for them as a result all were correctly filled and returned. The schools principals in all the sample schools were also interviewed. 
Table 3.2 Characteristics of the respondents

\begin{tabular}{|c|c|c|c|c|c|}
\hline S.No & Respondents & \multicolumn{2}{|l|}{ Characteristics } & $\mathrm{N}$ & $\%$ \\
\hline \multirow[t]{8}{*}{1} & \multirow[t]{8}{*}{ Natural Science teachers } & \multirow[t]{2}{*}{ Sex } & $\mathrm{M}$ & 58 & $81 \%$ \\
\hline & & & $\mathrm{F}$ & 14 & $19 \%$ \\
\hline & & \multirow[t]{3}{*}{ Qualification } & Diploma & - & \\
\hline & & & Digree & 72 & $100 \%$ \\
\hline & & & Above BSc/Bed & - & \\
\hline & & \multirow[t]{3}{*}{ Year of experience } & $0-5$ years & 34 & $47 \%$ \\
\hline & & & $5-10$ years & 25 & $35 \%$ \\
\hline & & & Above 10 years & 13 & $18 \%$ \\
\hline \multirow[t]{5}{*}{2} & \multirow[t]{5}{*}{ School principals } & \multirow[t]{3}{*}{ Qualification } & Diploma & & \\
\hline & & & Degree & 7 & $58 \%$ \\
\hline & & & Above BSc/Bed & 5 & $42 \%$ \\
\hline & & \multirow[t]{2}{*}{ Year of experience } & $0-5$ years & 3 & $25 \%$ \\
\hline & & & $5-10$ years & 5 & $42 \%$ \\
\hline 3 & & & Above 10years & 4 & $33 \%$ \\
\hline \multirow[t]{2}{*}{4} & \multirow[t]{2}{*}{ Students } & \multirow[t]{2}{*}{ Sex } & $\mathrm{M}$ & 215 & $53 \%$ \\
\hline & & & $\mathrm{F}$ & 189 & $47 \%$ \\
\hline
\end{tabular}

\subsection{Data analysis Methods}

Using the instruments listed in the previous chapters both qualitative and quantitative data were gathered. The data gathered through close-ended questionnaire for students, close-ended questionnaire for science teachers, and observation checklists were tallied, counted and systematically tabulated and analyzed quantitatively using descriptive statistics such as frequency, percentage and mean. The data gathered through open ended questionnaire from natural science teachers were also organized in quantitative form and tabulated. The data gathered through interview with school principals were analyzed qualitatively. Their responses were quoted during analysis of other quantitative data.

\subsection{Data Analysis}

3.3 Effect of training provided by Madda Walabu University on Laboratory work (2013-2015) in natural science for the selected Secondary Schools in Bale Zone.

Questionnaires were administered to trained natural science teachers to analyze the effect of the training provided by Madda Walabu University on Laboratory work (2013-2015). The questionnaires were designed to measure the effect of the training in their work experience, and the change observed in school practices on laboratory work $\mathrm{s}$ as a result of the training. The closed ended parts of the questionnaire were tabulated as follows while the openended responses were qualitatively analyzed where important. 
Table 3.2: Questionnaire for trained science teachers

\begin{tabular}{|c|c|c|c|c|}
\hline S.No & Question & Response & frequency & $\%$ \\
\hline 1 & When did you take the training provided by the University & & & \\
\hline \multirow[t]{2}{*}{2} & \multirow{2}{*}{$\begin{array}{l}\text { Is the training provided by Madda Walabu University adequate to } \\
\text { enable the science teacher to implement the laboratory work } \mathrm{s} \text { in } \\
\text { science? }\end{array}$} & Yes & 2 & 22 \\
\hline & & No & 7 & 78 \\
\hline 3 & $\begin{array}{l}\text { If the answer to question number } 2 \text { is 'No', what were the limitations } \\
\text { of the training? }\end{array}$ & & & \\
\hline \multirow[t]{3}{*}{4} & \multirow[t]{3}{*}{ Are you implementing the skills you received from the training? } & Always & - & - \\
\hline & & sometimes & 1 & $11 \%$ \\
\hline & & Not at all & 8 & $89 \%$ \\
\hline 5 & $\begin{array}{l}\text { If the answer to question number } 4 \text { is 'Sometimes' or' not at all', what } \\
\text { are the factors that hindered you to implement the values of the } \\
\text { training? }\end{array}$ & & & \\
\hline \multirow[t]{2}{*}{6} & \multirow{2}{*}{$\begin{array}{l}\text { Is there any change in implementation of laboratory work } \mathrm{s} \text { in your } \\
\text { school after your staff took the training? }\end{array}$} & Yes & - & \\
\hline & & No & 9 & 100 \\
\hline 7 & If the answer to question number 6 is yes, what are the changes? & & & \\
\hline 8 & If the answer to question number 5 is No, why there is no change? & & & \\
\hline \multirow[t]{5}{*}{9} & How do you rate the training provided by the University & Excellent & - & \\
\hline & & Very good & - & \\
\hline & & Good & 6 & 67 \\
\hline & & Fair & 3 & 33 \\
\hline & & Poor & - & - \\
\hline
\end{tabular}

As it is indicated in question No 2 in the table 3.2 above, most (78\%) of the responses indicate that the training was not adequate. An open ended questionnaire "what were the limitations of the training?" was administered to the trained teachers. The respondents replied that only few teachers participated in the training; No follow ups from responsible bodies; it was only for a short period of time; it was superficial and no sufficient experience to implement the laboratory work; it was only for sorting out the existing material and not how to use it.

As the responses to question No 4 indicates, most of the teachers (89\%) are not implementing the skills they received from the training. Their responses to question No 5 indicate the hindering factors to implement the values of the training are Lack of laboratory technician; Lack of laboratory room; Lack of practical skills (being afraid to use the available materials); Lack of practical materials; Shortage of time (the major objective is to cover the wide content on the text book); Great work load (overcrowded schedule); Large number of students per class.

These are also in agreement with other research findings. Mokotedi (2013) found that the main factors for the failure of implementation of laboratory work s include: lack of laboratories and equipment; lack of laboratory technicians; and large classes. These same factors are mentioned by principals of the schools when they respond to the interview question "What are the factors positively or negatively affecting the implementation of practical activities?" They also added lack of motivation of the teachers as another important factor.

Research (Hattingh, 2007) also has indicated that teachers who are motivated to do laboratory work will find ways to do so even in the most poorly resourced of schools. Conversely those who are not motivated will not do laboratory work even when they have access to the best of resources. The responses to question No 6 also confirm the result of question No 4. All the teachers responded that there are no changes in implementation of laboratory work $\mathrm{s}$ in their schools as a result of the training.

Finally most of the respondents to question No $9(67 \%)$ rated the training as good. And the analysis of the results in table 3.2 indicated, the training provided by Madda Walabu University was not adequate and the trained teachers were not implementing the objectives of the training. The school also experienced no changes in laboratory work as a result of the training. The limitations of the training identified by analysis and the hindering factors mentioned by the respondents are the basic components of the findings that need due attention for further training to be conducted in the future.

\subsection{The status of implementation of science laboratory work in the sample schools which received the training and those sample schools which were not included in the training}

To compare the extent of implementation of science laboratory work in the sample schools which took the training and those sample schools which did not take the training, checklists of laboratory work specified in the curriculum were prepared their level of presence in the sample schools were documented as indicated in the table 3.3. 
Table3.3: The status of implementation of science laboratory work $\mathrm{s}$ in the schools which receive the training and those which did not receive the training [None of the practical activities implemented (X), Less than $50 \%$ of the practical activities are implemented $(\mathbb{X})$, More than $50 \%$ of the practical activities are implemented $(\sqrt{ })]$

\begin{tabular}{|c|c|c|c|c|c|c|}
\hline & \multirow[t]{2}{*}{ S.No } & \multirow{2}{*}{$\begin{array}{l}\text { Name of the } \\
\text { school }\end{array}$} & \multicolumn{3}{|c|}{ Laboratory work implementation status for each subject } & \multirow[t]{2}{*}{ Remark } \\
\hline & & & Biology & Chemistry & Physics & \\
\hline \multirow{3}{*}{ 矛 } & 1 & Agarfa & $\mathrm{X}$ & $\mathrm{X}$ & $\mathrm{X}$ & \\
\hline & 2 & Goro & $\mathrm{X}$ & $\mathrm{X}$ & $\mathrm{X}$ & \\
\hline & 3 & Ginnir & $\sqrt{ }$ & $\sqrt{ }$ & $\sqrt{ }$ & \\
\hline \multirow{3}{*}{ 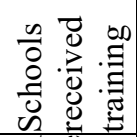 } & 4 & Gasara & $\mathrm{X}$ & $\mathrm{X}$ & $\mathrm{X}$ & \\
\hline & 5 & Walabu & $\mathrm{X}$ & $\mathrm{X}$ & $\mathrm{X}$ & \\
\hline & 6 & Dallo Manna & $\mathrm{X}$ & $\mathrm{X}$ & $\mathrm{X}$ & \\
\hline \multirow{2}{*}{ 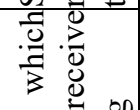 } & 7 & Galama & $\mathrm{X}$ & $\mathrm{X}$ & $\mathrm{X}$ & \\
\hline & 8 & Negadde & $\boldsymbol{x}$ & x & $\mathbf{x}$ & \\
\hline$=00$ & 9 & Maliyu Burka & $X$ & $\mathrm{X}$ & $\mathrm{X}$ & \\
\hline \multirow{3}{*}{ 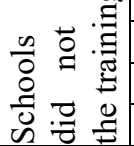 } & 10 & Sanbitu & $\mathrm{X}$ & $\mathrm{X}$ & $\mathrm{X}$ & \\
\hline & 11 & Sofumer & $\mathrm{X}$ & $X$ & $X$ & \\
\hline & 12 & Melka Micca & $\mathrm{X}$ & $\mathrm{X}$ & $\mathrm{X}$ & \\
\hline
\end{tabular}

As it can be seen from table 3.4 above, there is no difference in implementation status of laboratory work in schools which took the training and those schools which did not take the training. The practical activities were better exercised in Ginnir (which took the training) and partially practiced in Negade (which did not take the training) secondary schools. The interview with the corresponding principals shows that the changes were because of the efforts of the schools (material and professional supports from NGO). Therefore, these changes cannot be acknowledged as the results of the training. The practical component of the curriculum was equally neglected in both trained and none-trained schools. This indicates that there is no change in laboratory work in the schools as a result of the training. This is also in agreement with the responses of the trained teachers as discussed in the preceding section.

Some research finding indicates that reason for very little implementing practical activities were lack of concern and support of school principals (Endalamaw and et al., 2017). Adequate planning by the school head, with appropriate involvement of teachers, learners, parents and the community, can raise curriculum standards and help the school meet learning achievement goals and successfully implement their important policy directives or targets.

\section{Summery, conclusion and recommendation}

\subsection{Summery}

The objectives of this study were to analyze the effect of training provided by Madda Walabu University on Laboratory work (2013-2015) in science for the selected Secondary Schools in Bale Zone and to compare the extent of implementation of science laboratory work $\mathrm{s}$ between the schools which received the training and those which were not included in the training. To achieve these objectives important Data were collected from 404 students, 72 natural science teachers, and 12 school principals using questionnaires and interview. Observation checklists were also used to assess the school facilities for the implementation of laboratory work. The collected data were analyzed using descriptive statistics (frequency, mean and percentage). Because the trained teachers described it only few teachers participated in the training, No follow ups, the training was only for a short period of time, the training was superficial and no sufficient experience to implement the laboratory work. The training was only sorting out the existing material and not how to use it.

The data analysis also shows that there are no changes in the implementation of laboratory work $\mathrm{s}$ as a result of the training. Comparison was made between schools which took the training and those which did not take the training. The result shows that the laboratory works were equally neglected in both trained and non-trained sample schools. There are no tangible differences in both schools those were trained and those were not trained.

A comparison was made between the schools which took the training as those schools which did not take the training on the status of implementation of laboratory work. The result shows no difference in the implementation status. The data shows poor facilities in both trained and non-trained schools, and there are no conducive grounds in which even a practically skilled teacher exercises his skill. The major challenges for the implementation of laboratory work s as well as the implementation the skills training were identified to be: large class side, Lack of school facilities (lab room, lab technician, lab material, lab manual), lack of professional support, and great work load.

On the bases of the findings of the study it is recommended that Practical skill training is not the only requirement for the implementation of laboratory work. Prior to the training the school environment should be facilitated to handle the implementation of the laboratory work. The skill training is not required in the schools 
with poor facilities. The implementation of laboratory work does not immediately follow from the printed curriculum materials. The educational offices should seriously plan and enforce the provision of the required facilities for the schools and professional support for the teachers.

\section{References}

1. Endalamaw, D., Abebe, A., Meareg, G., (2017). An Investigation in to the Combined and Relative Influences of Some Selected Factors on Students' Performance in Physics Among Secondary Schools of Bale Zone, South East Ethiopia.Journal of Education and Practice.8, 19.

2. Feyera, B. (2014).Major Factors that Affect Grade 10 Students' Academic Achievement in Science Education at Ilu Ababora General Secondary of Oromia Regional State, Ethiopia International Letters of Social and Humanistic Science. 32: 118-134

3. Hattingh, A. \& Rogan, J. (2007) Some factors influencing the quality of laboratory work in science classrooms. African Journal of Research in SMT Education, 11(1): 75-90.

4. Kolucki, B. \&Lemish, D. (2011). Communicating with Children Principles and Practices to Nurture, Inspire, Excite, Educate and Heal. UNICEF.

5. Mokotedi, R.T. (2013).Beginning Primary School Teachers' Perspectives on the Role of Subject Specialization in Botswana Colleges of Education: Implications for the Professional Development of those who did not Specialize

6. Onwu, G., Stoffel, N. (2005) Instructional functions in large, under-resourced science classes: Perspectives of South African teachers. Perspectives in Education, 23(3): 65-75.

7. Ramnarain, U. (2014). Teachers' perceptions of inquiry-based learning in urban, suburban, township and rural high schools: The context specificity of science curriculum implementation in South Africa. Teaching and Teacher Education, 38: 65-75.

8. Science Community Representing Education, SCORE. (2008). Laboratory work in science: a report and proposal for a strategic framework. London: Science Community Representing Education (SCORE). Science Review, 91 (335), 49-51. 